\title{
Malaysia-Singapore-Thailand Capital Accumulation Growth (MST-CAG)
}

\author{
Suppanunta Romprasert
}

\begin{abstract}
Paper has presented ideal of capital accumulation growth by using Solow Growth Model for Malaysia, Singapore, and Thailand case. Based on past 10 years by those three countries, the economies have expanded. The investment on infrastructure also shows as a part of country's sustained economic growth such as telecommunications, electricity and ports. In the same time countries are experiencing a growing in shortage of skilled technical personnel. Then, paper's objective is to examine whether growth of countries is due to countries' capital accumulation. This objective brings to research question that "Why do developing countries (Malaysia and Thailand) grow at the same rates as developed one (Singapore)?" Scope of research is started at 1990 and ended at 2013. After analyzing the 24-year data collected and simulating those data with Solow growth model and basic model. Paper shows results as higher savings rate and higher gross fixed capital formation per worker lead to higher investment per person, and pull up steady-state level of capital. Moreover, increasing on literacy rate represents human capital that leads to growth of gross domestic product. Paper also benefits policymakers who are trying to implement such a policy to speed up economy in terms of economic growth and higher standard of livings including the well-being of people.
\end{abstract}

Index Terms-Capital accumulation growth, solow growth model, endogenous model, sustainability.

\section{INTRODUCTION}

Asian economic community (AEC) is counted as one of newly ASIAN continental economic integration. An opportunity for partner countries would be key economic driver especially on consumer-based markets. Therefore, it appears to be region of chances for ASIAN companies to grow for quick-transferring consumer goods and services businesses in next few years. Regarding to specific information above and supporting by Romprasert [1] states that Asian has one activity highlight in exports with free transferring of goods and services, investment, skill labors and free flow of capital. Cooperation on regional countries can support regional involvement to the world stage and increase regional economic huge among those countries. Importantly, Asian have been recognized in the role of science and technology which this role is creating economic growth including to manage of integration [2]. The integration can have positive effect by raising enough of financial support and giving chances to some institutions within region. There is growing realize that the power economies of some Asian member such as Malaysia, Singapore and Thailand is getting on a number of important

Manuscript received January 20, 2015; revised March 25, 2015.

R. Suppanunta is with the Business Economics Department, Assumption University Suvarnabhumi Campus, Bang Sao Thong, BKK 10250 Thailand (e-mail: suppanuntaMkk@au.edu). economic concept used to measure than others. Based on the past 10 years by those three countries, the economies of Malaysia, Singapore, and Thailand countries (MST countries) have expanded. The GDP at current prices shows that Malaysia, Singapore, and Thailand countries economy has in the top ranked economy in Asian. Although the economy has grown increasingly, but the future performance of those countries must be depended on continued reform of financial sector and increasing exports. The investment on infrastructure also shows as a part of sustained economic growth such as telecommunications, electricity and ports making Malaysia, Singapore, and Thailand countries are experiencing a growing shortage of skilled technical personnel. According to information above, paper's objective is to examine whether growth of Malaysia, Singapore and Thailand is due to countries' capital accumulation by applying Solow growth model as a part of Macroeconomic. This objective brings to the research question that "Why do developing country (Malaysia and Thailand) grow at the same rates as developed one (Singapore)?" This might be implied in the sense of factors potential influences affecting economic growth of a country that can improve and find the best solution to make country grow faster, and achieve sustainability. Furthermore, goal of policymakers is one important factor to raise standard of livings in country.

The scope of this research is to study economic growth of Malaysia, Singapore, and Thailand countries during 1990 through 2013 based on Solow growth model and endogenous growth theory. The research tries not to extend the study beyond economic growth resulting from capital accumulation of countries. Higher standard of livings from Malaysia, Singapore, and Thailand countries come directly from higher potential growth of countries' GDP per capita. Thus, the other factors except capital accumulation that can influence economic growth are out of paper's consideration.

\section{LITERATURE REVIEW}

\section{A. Article Review}

Singapore is one of ASIAN countries that faces high investment in human capital. It attracts foreign investment and welcome international experts including administrative of multinational firms which country particular develops a talent capital where knowledge and skills of people become competitive advantages [3]. Increasing in capital stock of export sector is main reason effecting falling in unemployment rate of Singapore making country's economy expands [4]. Ngoc [5] says that labor can be counted as an essential element that foreign businesses obviously concern about a large supply of labor relatively to capital stock. For Asian 12 countries, growth rate of labor force and rate of 
technological change enter as important determinants on steady state [6]. This information means that in long run, capital-output ratio depends on country's level of human capital. In recent year, the world is truly characterized with free capital mobility [7]-[9] Klein and Olivei [9] including ASIAN Community, no strong relationship between savings and investment appears. However, one cannot deny that in reality both savings and investment variables are still closely related. The relationship shows as "Higher savings rates would increase investment expenditure which requires more capital as an input factor" [10]-[12]. Another factor that may involve with human capital but not directly related that is educational background of individuals in each country. It can be part of demonstrating in human capital and also comes along with sustainable economic growth [13]. Because this part of human capital can be explained by family income of each household in terms of ability to support their child's educational background to acquire more experiences and higher skills [14]. The high education provides good opportunity in future that perhaps offers high income and increases productivity [12]. Income-based approach is closely related to each individual's benefits obtained by investment in education and training [15].

\section{B. Theoretical Review}

Consequently, paper conducts research based on some of following functions, theories, and models: in order to turn Malaysia, Singapore, and Thailand countries into an attractive world of people' minds, talents, ideas, and knowledge as well as a place where opportunities are plentiful so that entrepreneurs and investors would like to live and to work, "Manpower 21" strategy was established [15]. The strategy involves in developing human capital where knowledge, skills and attitudes of people become competitive advantage. The foreign man-power is divided into two categories as suggested by Kwon [15]: (1) International Talent and (2) General Foreign Worker category. Kee and Hoon [4] use Cobb-Douglas production function built in their research paper and conclude that capital accumulation is the most important determinant of economic growth, while labor and technological progress have few impacts. It means capital stock is a main determinant in describing growth particular for industrialized and developing countries including uses for differences in standard of living among countries. Countries that have had large raises in their capital stock have also shown in a huge increase in their GDP [16]. On selecting capital stock, marginal product of capital (MPK) is important for explaining. High product growth was driven by rapid growth in capital stock [17]. Physical capital accumulation in an open-economy growth model is adopted to explain physical capital population ratio which refers to: $(1-t) * M P K=r^{w}$ where $r$ is world real interest rate considered exogenous, and $t$ is tax rate broadly defined. In the case on without population growth and technological progress, one assumes that production function presents as a Cobb-Douglas form: $Y=A K^{\alpha} L^{(1-\alpha)}$ where $Y$ is output, $A$ is a positive constant, $K$ is physical capital and $L$ is labor. For the level of investment, $I$, as the steady state requires: $I=\delta \mathrm{K}$ where $\delta$ is the depreciation rate, it has a one-to-one correlation between investment and physical capital.
Furthermore, on considering in a possible role of human capital, simply introducing ' $H$ ' into the Cobb-Douglas production function in a labor augmenting way would not change anything fundamentally. An interesting case of $\mathrm{K}-\mathrm{H}$ complementarity is: $Y=A^{*}\left(K^{\rho} H^{\rho}\right)^{\alpha / \rho} *(X-L)^{1-\alpha}$ where $H$ is level of human capital and $X$ is level of technology. This theory also shows the factors affecting growth rates of physical capital per capita. Those factors are as follows: Initial physical capital per worker, Investment Efficiency, Initial technology level, Technological growth rate, Human capital, Industrial structure, Population growth rate, Savings rate, Relative price of investment goods, Lagged growth rate of physical capital per worker [18]. A rightward shift of steady state implies an expansion of production-possibility boundary meaning that county has achieved economic growth. Neoclassical growth model is known as Solow growth model can explain economic growth due to accumulation of capital stock, whereas endogenous growth theory, or basic model can explain economic growth arising from accumulation of human capital [2], [19]-[21]. Once capital stock grows, economy moves toward a higher steady stead. Then production possibility frontier curve shifts outward implying to an economic expansion and the better standard of livings of people in country. Obviously, savings rate and per-worker capital stock both play important roles in falling and rising in an economy's steady state. Since physical capital exhibits diminishing returns to scale, while human capital exhibits increasing returns to scale, idea of Solow growth model does not apply to the case of human capital. Thus, paper needs to adopt basic model to explain economic growth resulting from human capital accumulation.

\section{RESEARCH METHODOLOGY}

\section{A. Data Preparation}

Annual data are collected from the Malaysia, Singapore, and Thailand Department of Statistics and the World Bank for 24 years, from 1990 to 2013. The studied variables are real GDP and per-capita GDP, gross fixed capital formation, savings rates, and literacy rates.

\section{B. Conceptual Framework}

Regarding to the articles and the theoretical reviews, one can then construct conceptual framework displaying. Apparently, physical and human capitals are parts of capital accumulation. The MST's capital accumulation influences economic growth of countries which are represented by growth trend of GDP per capita. Paper applies gross fixed capital formation and savings rate as the proxy to determine physical, and applies literacy rate as the proxy to determine national human capital. Solow growth model uses to simulate physical capital, whereas endogenous growth theory uses to explain human capital.

\section{DISCUSSIONS AND ANALYSIS}

\section{A. Data Analysis}

1) Physical capital: The solow growth model perspective The paper focuses on two variables affecting physical 
capital accumulation those are gross fixed capital formation per worker and savings rate. Since total investment is an essential component of national income equation: $Y=C+$ $I+G+X-M$. For simplicity, one assumes that Malaysia, Singapore, and Thailand countries are small-closed economy meaning that they do not trade with the rest of the world; also, government spending has small effects on economy. The paper assumes that there are only two input factors that are utilized to product goods: capital $(K)$ and labor $(L)$. As a result, the supply of goods depends solely on those two variables: $Y=F(K, L)$. Divided both sides of the equation by L to get per-worker terms: $\frac{Y}{L}=F\left(\frac{K}{L}, \frac{L}{L}\right) ; y=f(k)$. So, the investment function can be written as: $i=s f(k)$. This implies that savings rate and physical capital per worker influence the investment per worker. By looking at the trends of gross fixed capital formation per worker and savings rate of Malaysia, Singapore, and Thailand countries, the trends can tell about possible movements of investment curve of the country showing in Fig. 1 and Fig. 2.

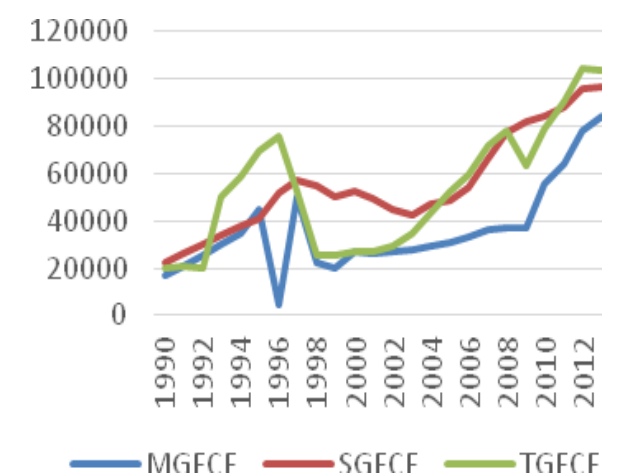

Fig. 1. M-S-T Gross Fixed Capital Formation (US \$).

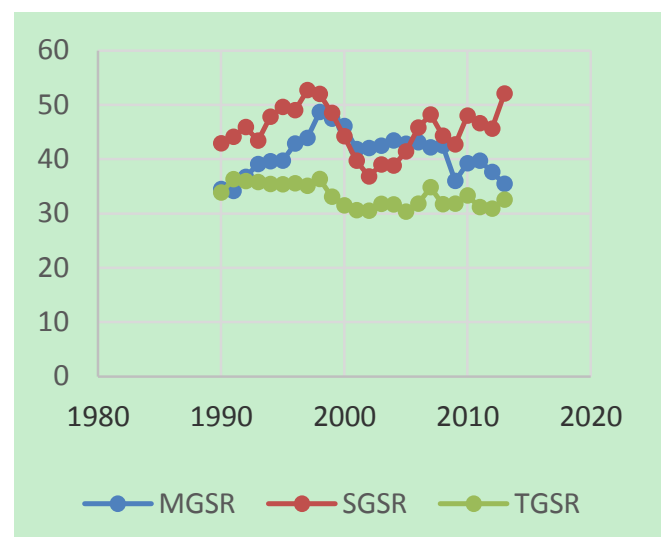

Fig. 2. M-S-T Gross Saving Rate (\% of GDP).

The capital formation explains the concept of macroeconomics because it uses to measure net additions to capital stock of country referring to saving drives and public borrowing. The Fig. 1 is apparent that gross fixed capital per worker of Malaysia, Singapore, and Thailand countries has been raised since year 2002. However, both Malaysia and Thailand during 2009, gross fixed capital per worker is dropped. This dropped can be corresponded to Fig. 2 on gross saving rate as because capital formation is the transferring of savings from household sector to business sector directly through investments or indirectly through commercial bank's reserve which are acted as excess reserve to firms. Both Fig. 1 and 2 shows that since year 2002, Malaysia, Singapore, and Thailand countries have been saved rose up affecting to capacity of commercial banks in those countries to loan more for firms. The businesses can invests more and create higher real GDP for their countries. However, during year 2009 Thailand and Malaysia have been faced on political problem that make the dropped in saving making commercial banks less opportunity to loan for firms. But after passing that crisis both countries can recovered again which gross fixed capital formation and gross saving rate are increasing.

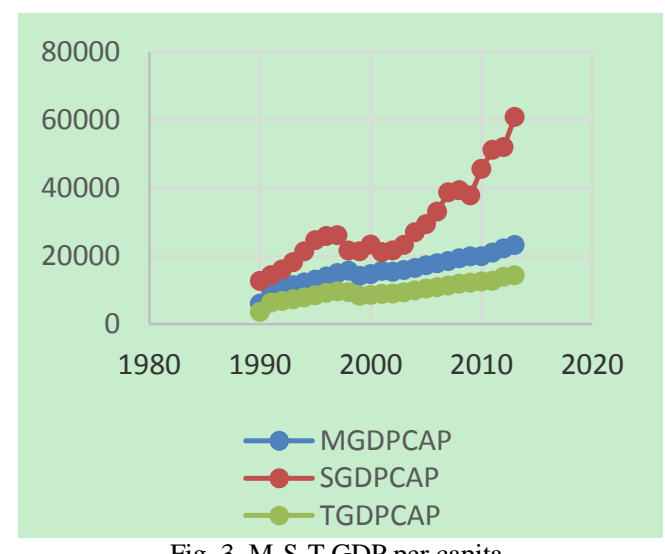

Fig. 3. M-S-T GDP per capita.

Singapore, Malaysia and Thailand's GDP per capita in Fig. 3 has been raised from 1990 to 1997 and slightly declined in a few years later before starting a large expansion in the year 2002 up till now. Since investment per worker is a component of national income. Furthermore, investment per worker is determined by national savings rate and capital stock per worker which is represented by gross fixed capital formation per worker in paper. Then, the increased in those two variables result in increasing investment per worker, which in turn, increases output per worker.

\section{2) Human capital: The basic model perspective}

Moreover, paper focuses on literacy rate that can measure on human capital of countries. Since human capital does not exhibit diminishing returns to scale like physical capital, paper adopts concept of basic model to analyze human capital toward countries' economic growth. Starting with production function: $Y=\mathrm{AK}$. It represents levels of output produced using only human capital. This means human capital which is used adult literacy rate as proxy directly affects to aggregate output or national income of country. By checking at trend of literacy rate of adult Singaporeans, Malaysians, and Thais, it shows in Fig. 4.

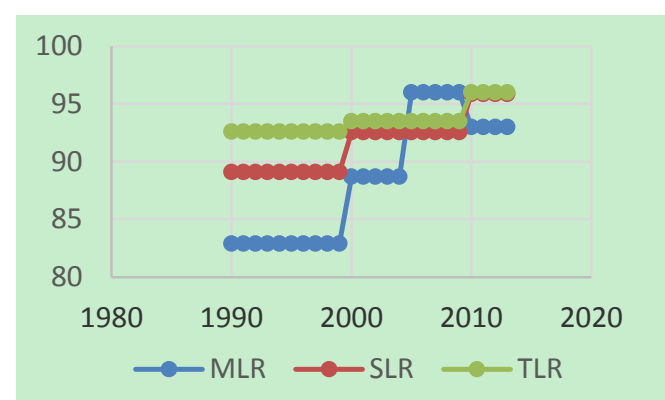

Fig. 4. Adult total literacy rate (\% of people ages 15 and above).

Literacy is ability to read and write; moreover, it is a set of abilities to understand and use symbol of a culture for community. However, the key is reading development with ability to speak words and write words in deep understanding 
of text. Fig. 4 shows that literacy rate of Malaysia, Singapore, and Thailand citizens has been increased during research period. Although this type of data is normally collected once a decade, it really illustrates a rising trend for all countries. On the other hands, the higher the literacy rate, the higher the GDP. That means citizens of each country are able to create in a huge profit with an education. However, if country has a high GDP, the government is able to fund more towards national education shown in Fig. 5.

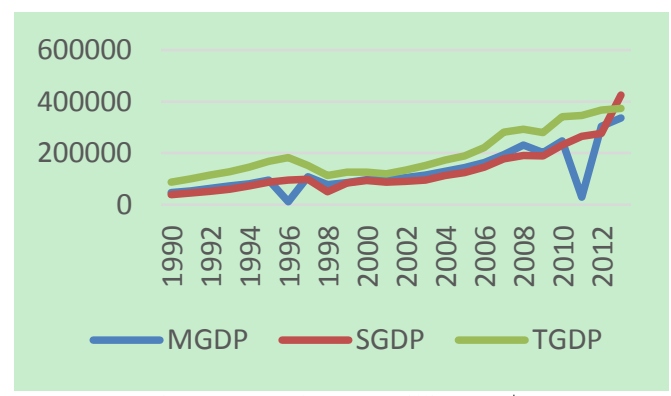

Fig. 5. Annual GDP (million US\$).

Trend of Thailand, Malaysia, and Singapore's annual GDP corresponds to that of the adult literacy rate. It has been moved over time from 1990 to 2013 for all of countries. Since human capital $(K)$ is a component of production function: $Y=$ $A K$, the higher literacy rate results in the increase in the country's real GDP.

\section{B. Comparison to Theories}

A change in capital stock per worker is computed by total investment per worker minus depreciation of capital invested, mathematically expressed as: $\Delta k=i-\delta k$ since $i=s y$ and $y=f(k)$, it can be written as: $\Delta k=s f(k)-\delta k$. Let term $\Delta k$ be zero to satisfy steady state's condition: $0=s f\left(k^{*}\right)-\delta k^{*}$, then $s f\left(k^{*}\right)=\delta k^{*}$ where $k^{*}$ is steady-state level of capital. The equation implies that at a steady state, total investment per worker equals total depreciation of capital invested. In addition, one assumes that depreciation rate $(\delta)$ is fixed including a Cobb-Douglas production function: $Y=K^{0.5} L^{0.5}$, where both capital and labor are utilized at the same proportion for production process. To derive output per worker function, divided both sides of equation by $L: \frac{Y}{L}=\frac{K^{0.5} L^{0.5}}{L} ; y=\left(\frac{K}{L}\right)^{0.5} ; y=k^{0.5}=$ $\sqrt{k}$. Substituting $y=f(k)=\sqrt{k}$ into the steady state function: $s \sqrt{k^{*}}=\delta k^{*}$ and rearranging to get: $k^{*}=\left(\frac{s}{\delta}\right)^{2}$. Therefore, paper examines steady-state levels of capital by choosing 1990 for Malaysia, uses 2002 for Singapore, and uses 2005 for Thailand as base year. Furthermore, the most recent year studied be 2013 in order to ensure whether Malaysia, Singapore and Thailand's steady state is higher.

In 1990, the savings rate for Malaysia is $34.48 \%$; so, the steady-state level of capital stock is $k_{1990}^{*}=\left(\frac{0.3448}{\delta}\right)^{2}=$ $\frac{0.1189}{\delta^{2}}$.

In 2013, the savings rate for Malaysia is $35.45 \%$; so, the steady-state level of capital stock is $k_{2013}^{*}=\left(\frac{0.3545}{\delta}\right)^{2}=$ $\frac{0.126}{\delta^{2}}=0.007 k_{1990}^{*}$

In 2002, the savings rate for Singapore is $36.80 \%$; so, the steady-state level of capital stock is $k_{2002}^{*}=\left(\frac{0.368}{\delta}\right)^{2}=\frac{0.135}{\delta^{2}}$.

In 2013, the savings rate for Singapore is $52.07 \%$; so, the steady-state level of capital stock is $k_{2013}^{*}=\left(\frac{0.521}{\delta}\right)^{2}=$ $\frac{0.271}{\delta^{2}}=0.136 k_{2002}^{*}$

In 2005, the savings rate for Thailand is $30.32 \%$; so, the steady-state level of capital stock is $k_{2005}^{*}=\left(\frac{0.3032}{\delta}\right)^{2}=$ $\frac{0.092}{\delta^{2}}$

In 2013, the savings rate for Thailand is $32.53 \%$; so, the steady-state level of capital stock is $k_{2013}^{*}=\left(\frac{0.3253}{\delta}\right)^{2}=$ $\frac{0.106}{\delta^{2}}=0.014 k_{2005}^{*}$.

As a result, the steady-state levels of capital stock in 2013 of Malaysia, Singapore and Thailand are higher than those in the base year. Since the steady-state level of capital stock is higher, the production-possibility boundary expands implying the economic growth of Malaysia, Singapore, and Thailand countries. The steady-state level of capital in 2013 for Malaysia, Singapore, and Thailand is the highest 0.07, 1.36 , and 0.14 times of each country base year's level respectively. The reason behind this is that savings rate of 2013 is greater than that of base year for each country. The increase in savings rate would raise investment per capital. Once country has more capital stocks, it can provide and use larger amount of capital for production. Moreover, it can produce more units of goods and services. Therefore, the production-possibility frontier for country has a parallel outward shift.

\section{CONCLUSIONS}

The accumulations of both physical and human capital allow a country to fully utilize the resources for productions. Once greater units of outputs are produced and are sold, country's GDP and national income can increase meaning that an economic growth is reached. Different countries grow at different rates because they are at different steady states. A steady state implies a balanced growth of economy where it does not have any changes in capital stocks. So, the level of output is steady over time as capital stocks are steady, and there is no pressure for capital to either fall or rise. The countries with high steady-state levels of capital should grow much faster than those with low levels. Undoubtedly, if a country can boost its steady state, then production possibility frontier exhibits a parallel outward shift indicating a faster economic growth. In addition, a poor country can grow at the same rate as rich countries, or can accelerate its growth rate, by locating steady states of the rich and raising its accumulation of capital stock to be at the same level as the rich's. Once the countries share the same steady state, they can eventually grow at the same rate, then they should be as wealthy as each other.

\section{RECOMMENDATIONS}

This paper can be used as a starting point for further studies about capital accumulation and economic growth in very deep and particular details. Paper also benefits policymakers who are trying to implement such a policy to 
speed up economy in terms of economic growth and higher standard of livings including well-being of people.

\section{REFERENCES}

[1] S. Romprasert, "Asian economic community with selected macroeconomic variables for exports sustainability," International Journal of Economics and Financial Issues, vol. 3, no. 3, pp. 602-605, 2013.

[2] R. J. Barro, N. G. Mankiw, and X. Sala-i-Martin, "Capital mobility in neoclassical models of growth," American Economic Review, vol. 85 no. 1 , pp. $103-115,1995$.

[3] B. B. Bhasin and P. L. K. Cheng, "The fight for global talent: New directions, new competitors - A case study on Singapore," Section 2: Practitioner Papers, pp. 2-6, 2001.

[4] H. L. Kee and H. T. Hoon, "Trade, capital accumulation and structural unemployment: Empirical study of the Singapore economy," Journal of Development Economics, vol. 77, no. 1, pp. 125-152, 2005.

[5] P. M. Ngoc, The Roles of Capital and Technological Progress in Vietnam's Economic Growth, vol. 2, no. 9, pp. 15-17, 2007.

[6] E. Shioji and V. T. Khai, "Physical capital accumulation in Asia 12: Past trends and future projections," Japan and the World Economy, pp. 3-20, 2010.

[7] A. Alesina, G. Vittorio, and M. M. Gian, "The political economy of capital controls," in Capital Mobility: The Impact on Consumption, Investment and Growth, L. Leiderman and A. Razin, Eds. Cambridge, New York and Melbourne: Cambridge University Press, 1994, pp. 289-321.

[8] J. Bhagwat, "The capital myth: The difference between trade in widgets and trade in dollars," Foreign Affairs, vol. 77, pp. 7-12, 1998.

[9] M. Klein and G. Olivei, "Capital account liberalization, financial depth and economic growth," NBER Working Paper 7384, 1999.

[10] O. P. Attanasio, L. Picci, and A. E. Scorcu, "Saving, growth, and investment: A macroeconomic analysis using a panel of countries," Review of Economics and Statistics, vol. 82, no. 2, pp. 182-211, 2000.

[11] M. S. Feldstein and C. Y. Horioka, "Domestic saving and international capital flows,” Economic Journal, vol. 90, no. 358, pp. 314-329, 1980

[12] J. Zhang, J. Zhang, and R. Lee, "Rising longevity, education, savings, and growth," Journal of Development Economics, vol. 70, pp. 83-101, 2003.

[13] M. Bils and P. J. Klenow, "Does schooling cause growth," American Economic Review, vol. 90, no. 5, 2000.

[14] J. Mincer, "Human capital and economic growth," Working Paper No. 803 , pp. $13-24,1981$
[15] D. B. Kwon, "Human capital and its measurement," in Proc. The 3rd OECD World Forum on Statistics, Knowledge and Policy, 2009, pp. 6-7.

[16] I. Castles and D. Henderson, "International Comparisons of GDP Issues of Theory and Practice," World Economics, vol. 6, no. 1, 2005.

[17] S. N. Durlauf and D. T. Quah, "The new empirics of economic growth," in Handbook of Macroeconomics, J. B. Taylor and M. Woodford, Eds. Vol. IA, North-Holland, Amsterdam, 1999, pp 231-304.

[18] P. Beaudry and F. Collard, "Recent technological and economic change among industrialized countries: Insights from population growth," Scandinavian Journal of Economics, vol. 105, no. 3, pp 441-463, 2003.

[19] R. J. Barro, "Economic growth in a cross section of countries," Quarterly Journal of Economics, vol. 106, no. 2, pp. 407-444, 1991.

[20] P. M. Romer, "Increasing returns and long-run growth," The Journal of Political Economy, vol. 94, no. 5, 1986.

[21] P. M. Romer, "Endogenous technological change," The Journal of Political Economy, vol. 98, no. 5, pp. 71-102, 1990

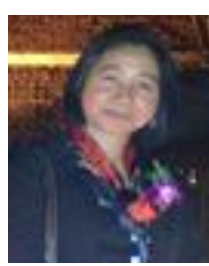

R. Suppanunta was born in Bangkok, Thailand on November 17, 1972. She got the B.Sc. Hons. degree in psychology from Srinakarinwirot University, Bangkok, Thailand in May 1995; the master degree in human resource development from National Institution Development Administration, Bangkok, Thailand in November 1997; the PDSC degree of economic from Saskatchewan University, Canada in October 2002; the master degree in economics from Saskatchewan University, Canada in May 2003; the doctoral degree in economics from National Institute of Development Administration, Bangkok, Thailand in May 2009. She had been working in both private companies and educational institution experiences, including scholarship in both domestic and abroad. Her current job is in business economics, Martin de Tours School of Management and Economics, Assumption University, Thailand as a full-time lecture.

Asst. Prof. Dr. Suppanunta has been reviewed articles for National Institute of Development Administration. Moreover, she receives the honorable mention on best paper award of KUJE 15 from Kasetsart University, Thailand and excellent honorable mention on research article in $\mathrm{PhD}$ level from National Institute of Development Administration, Thailand. 